\title{
Persian Archery and Swordsmandship: Historical Martial Arts of Iran, by Manouchehr Moshtagh Khorasani
}

\author{
Bede DWYER* \\ Independent researcher (Australia)
}

Recepción: 25/02/2013; Aceptación: 25/02/2014; Publicación: 30/06/2014.

\section{Abstract}

This review covers the book, Persian Archery and Swordsmanship: Historical Martial Arts of Iran by Dr Manouchehr Moshtagh Khorasani. He is the author of several books in this field (Arms and Armor from Iran The Bronze Age to the End of the Qajar Period, 2006; Lexicon of Arms and Armor from Iran: A Study of Symbols and Terminology, 2010) and many important articles. The review looks at the nature of the book, its structure and layout. It discusses the problems inherent in presenting a complex account such as of the martial arts traditions of a region as extensive as the Iranian culture area. The potential audience is explored. A large selection of illustrations relevant to the text is included in the text while an extensive full color catalog is included as section 10 .
\end{abstract}

Keywords: Book review; martial arts; martial traditions; Persian culture; Persian swordsmanship; Persian archery.

\section{Persian Archery and Swordsmanship: Historical Martial Arts of Iran, por Manouchehr Moshtagh Khorasani}

\section{Resumen}

Esta revisión se centra en la obra Persian Archery and Swordsmanship: Historical Martial Arts of Iran, por el Dr. Manouchehr Moshtagh Khorasani, autor de varios libros (Arms and Armor from Iran The Bronze Age to the End of the Qajar Period, 2006; Lexicon of Arms and Armor from Iran: A Study of Symbols and Terminology, 2010) y numerosos artículos relevantes en este campo de conocimiento. La revisión considera la naturaleza, estructura y diseño de la obra. Discute los problemas inherentes a presentar un relato complejo sobre las tradiciones marciales de una región tan amplia como es el área cultural iraní. Se examina su público potencial. Esta obra incluye una amplia selección de ilustraciones y un catálogo a todo color en la sección 10.

Palabras clave: Revisión de libro; artes marciales; tradiciones marciales; cultura persa; esgrima persa; tiro con arco persa.
Persian Archery and Swordsmanship: Historical Martial Arts of Iran, por Manouchehr Moshtagh Khorasani

\section{Resumo}

Esta revisão centra-se na obra da Persian Archery and Swordsmanship: Historical Martial Arts of Iran, por o Dr. Manouchehr Moshtagh Khorasani. Este autor escreveu vários livros neste domínio de conhecimento (Arms and Armor from Iran The Bronze Age to the End of the Qajar Period, 2006; Lexicon of Arms and Armor from Iran: A Study of Symbols and Terminology, 2010) e numerosos artigos relevantes. Esta revisão considera a natureza, estrutura e desenho da obra. Discute os problemas inerentes de apresentar um relato complexo sobre as tradições marciais de um domínio tão amplo como é a área cultural iraniana. Examina-se o público potencial da sua obra. Esta inclui uma ampla seleção de ilustrações e um catálogo colorido na seção 10.

Palavras-chave: Revisão de livro; artes marciais; tradições marciais; cultura persa; esgrima persa; tiro com arco persa.

\section{1.- Introduction}

This is a review of Persian Archery and Swordsmanship (Khorasani, 2013). I have had a connection with this book before its publication; I consulted on the section on archery and worked with Dr Khorasani on other related articles (Dwyer \& Khorasani, 2013). However, Khorasani

*E-mail: bededw@tpg.com.au. 
conceived of the book, wrote the text, assembled the illustrations and organized the publication. In all senses, but one, I approached this book as much in the dark as any first time reader.

However, that sense, exchanging comments by email about the meaning of translated sentences, does not really prepare you for the scale of the whole work. It is a large book with a vast number of illustrations ${ }^{1}$, enough to qualify it for an art book on the depiction of weapons in Persian miniature painting. Paintings are not the only illustrations since there are many photographs of people going through various exercises with a variety of weapons. Though with a few exceptions these illustrations are small, the sequences and the clarity of printing allow them to be examined to the advantage of the reader. The large illustrations, both in black and white and in color, give an even better idea of the subjects being discussed. A catalog of weapons towards the end of the book shows in detailed color reproduction the high quality of design and execution that went into the production of arms and armor in Iran. Most of the equipment illustrated is from the time of the Safavids, Afsharids, Zands and Qajars ${ }^{2}$. These dynasties ruled a united Iran from the late fourteen hundreds to the early twentieth century. This book is about the military and sporting uses of weapons and combat forms that coalesced from the long history of Persia during that four hundred year period.

\section{2.- Background}

Iran, despite its long and distinct history, has a very multicultural past. The native Persians speaking Farsi, a language that has linguistic links back into ancient times, have lived next to and sometimes intermingled with Arabs, Armenians and Kurds for thousands of years. At about the time that New Persian stabilized into the modern language a thousand years ago, a new ethnic group, the nomadic Turks, began to play a larger part in Iranian history and in the ethnic makeup of the country. At one time, Persian was the language of the book (i.e. of the scribes and bureaucrats), Turkish was the language of the sword (i.e. the military) and Arabic was the language of jurisprudence. However, Persian gradually became the main language ${ }^{3}$ of the state and became so prestigious that literate people in neighboring Ottoman Turkey and Mogul India thought that knowledge of it was a necessary part of being an educated person. Despite the disruptions caused by Turkish tribal wars between the Seljuks and the Oguzz nomads and then the subsequent wars of the Khwarezmshahs and invasion of the Mongols under Chinggis Khan and his successors, Persian culture survived and even flourished. It is against the background of this resilience and vigor that is necessary to understand the complex nature of the martial arts in Iran.

Stretching back into the distant past was a tradition of heroes and mighty feats of arms epitomized in the nation epic the Shahnama. At the same time by the beginning of the Safavid era, there was also a long tradition of military professionalism and organized training which saw many Turkish boys trained to be professional soldiers by the Abassid Caliphs and various Persian dynasties like the Samanids. In the west we are better acquainted with this system as practiced by the Mamluks in Egypt and the Ottomans with their Janissaries. What all these systems have in common was rigorous training from a young age. Outside the military there was a separate strand of training based on local organizations, like the ayyārān, that developed their own militias for regional defense when the central government could not be depended upon to maintain order.

This complex environment produced several well developed martial arts around the major weapons, the bow, the sword, the dagger, the mace, the axe, and the spear. Underpinning this was a training regimen with wrestling as part of the development of individual skills. The military martial arts also had a dependence on the skill of the users in the art of horsemanship. The martial arts can

\footnotetext{
1 There are 2,095 images in the book including 1,564 photographs of technique, 303 details from miniatures in the text and 178 color photographs in the catalog. Other classes of picture make up the rest.

2 These dynasties ruled Iran as a whole since the time of the collapse of the Timurids. Their names reflect their origins. The Safavids were the dynasty founded by the charismatic Shah Ismail Safavi. The Zands were founded by Karim Khan Zand. The conqueror, Nadir Shah, was the principal Afsharid. The Qajars were founded by Ali Khan Qajar and lasted into the early twentieth century.

${ }^{3}$ While it was always the majority language of the country, Persian was not necessarily the main language of the ruling class.
} 
be divided up on the basis of the distance at which one engages the enemy. Archery is practiced at the greatest distance right down to a level where the archer cannot reload fast enough to defend himself. The spear and the lance can reach farther than other hand held weapons and some are even designed to be thrown, putting them with the missile weapons. The sword, the mace and the axe are close range weapons that put you within arms reach of your opponent. Knives and daggers put you within grappling range and subject to the skills of the wrestler. Occasionally other weapons are used like the lasso to entangle the opponent and there is always the defensive back up of shields and armor.

This book covers all these major groups. In a way its title is deceptive, Persian Archery and Swordsmandship suggests the two main sections, but the book includes all the martial arts as reflected in the rest of the title, Historical Martial Arts of Iran.

\section{3.- The Structure of the Book}

Persian Archery and Swordsmanship is made up from several different forms of content. There are discursive explanations of abstracts like chivalry and direct translations original manuals as in the case of archery. There are also several essays at the beginning of the book by specialist authors that discuss the main concepts in the work. A large part of the book is made up of explanations of techniques and terminology illustrated by photographed demonstrations and depictions in contemporary art. Diagrams are kept to a minimum. This makes it possible to track down a particular weapon, find out how it was used and see how it was referred to in literature. Since this is the first serious book on these subjects in the Persian context, it is to be expected that future research and practice will produce more specialist publications.

The combination of illustrations and text has relegated the notes to the end of the book ${ }^{4}$. Had the author chosen to use footnotes instead, the pages would have been too complex to follow. Had he chosen to use fewer and bigger illustrations some of the impact of the repeated connection between textual description from old books and the art of the time would be lost. The juxtaposition of citation of an old text and a contemporary painting gives a good idea of how far to trust the representational ideals of the artists of the time. The book has far too much information to read it as a single piece. The only way to get the most out of it is to read a section at a time, digest the ideas and go back and check out the illustrations and the quotations. The catalog, presented as chapter 10 provides full color photographs of many of the weapons described and illustrated in the main body of the work and is a great aid in appreciating the artistic effort put into these objects. The major sections are explained below, but each requires detailed study if it to be appreciated fully. A review is a guide to a book and the opinion of the reviewer about its quality and success in achieving the author's goals so I will start by describing the some of the sections of the book and hope that that will give some background to my opinions expressed later. The list of chapters is contained in an appendix at the end of this article.

\section{1.- The Code of Chivalry and Warrior Codex}

This opening section relates the basic underpinning of the morality of the warriors of the times discussed. In the West, we are aware of the stories of brave and noble knights and usually have some knowledge of the less edifying reality. However, the concept of a set of rules for acceptable behavior is familiar and there is much in this section that we can relate to. Even in the modern world there is discussion about the morality of battle in general and the proper behavior of the individual.

This particular section deals with the javānmardi ${ }^{5}$ and ayyārān $n^{6}$, who represent the popular face of chivalry in historical Iran

\footnotetext{
4 There are 2,189 notes in fine print making up a substantial part of the text.

${ }^{5}$ A chivalrous or manly person.

${ }^{6}$ A member of a local group originally dedicated to upholding morals and protecting the community.
} 


\section{2.- The Sacred Weapon: Archery in Iran}

This is the section that has the most new material direct from manuscript sources. The technical nature of archery, in its equipment and prosecution, provides many opportunities for learned discussion. Despite this, much of the literature is practical and straightforward. Luckily for the author and the reader, there are many points of comparison from already translated Arabic (Faris \& Elmer, 1945; Latham \& Paterson, 1970), Persian (McEwen, 1974) and Turkish manuals (Klopsteg, 1987; Öztopçu, 2002). The author has chosen to translate these pieces in a manner that preserves much of the original nature of the text. The individual manuscript sources have not been massaged into a more digestible English form. This preserves the original voice of the authors and emphasizes the ambiguity found in the texts. Some of the ambiguity is resolved in the notes and comparisons are made with other works on the same subject. It must be remembered that when these works were originally produced, the authors and the readers assumed an easy availability of teachers to explain and demonstrate the more obscure parts of the text. While there are many individual facts and insights that can be extracted from these translations, they have not been rearranged into a simple manual.

\section{3.- Combat with Spears and Lances in Iranian History}

Spears have been perennially popular weapons because of their low cost and potential for use in concert in large formations. This section concentrates on individual moves rather than the training of groups of spearmen and provides a basis for understanding the capabilities of the weapons in this family. Like the other sections, the literary references to spears and lances are examined and real techniques are derived from them. This is helped by the many surviving depictions of the use of the lance on horseback in Persian books. Comparisons can be made with furusiyya manuals ${ }^{7}$ in Arabic from Mamluk Egypt (Al-Sarraf, 2004). Thrown spears, javelins, are also discussed and further work on this subject will no doubt take place since there is a surviving sport in Turkey based on these weapons and many manuscripts to search for techniques.

\section{4.- Swordsmanship}

The production and the use of the sword have a long history in Iran and the sophistication of the design and use of Persian swords has been under-reported in Western publications. This section demonstrates techniques, relates them to literary descriptions and anchors them to real surviving weapons. It is comprehensive and forms the basis for some of the features of the discussion of spears and knives since the confrontation between the various weapons requires an understanding the capabilities of the opposing weapons.

\section{5.- Wrestling: An Integral Part of Combat in Iran}

Wrestling is a living sport in its traditional form as well as in modern forms. Today, teachers still can be found and old techniques explained. In many ways, this can give a good insight into the mindset of many of the martial arts while at the same time providing practical hands on experience. Despite its survival as a sport, the underlying martial art can easily be explored.

\section{4.- The Audience}

This book appeals to several different and quite specific audiences. The martial artist will find different forms to compare with his or her own traditions. The historian will find more depth than is usually available to compare what is known of what happened to the capabilities of the peoples of the time. In each of the major subjects, there is a specific audience. For archery and

\footnotetext{
7 Manuals on cavalry maneuvers and fighting on horseback were popular for centuries and many survive from the period of Mamluk rule in Egypt and Syria in Arabic (Scanlon, 2012) and also in Turkish paraphrase (Öztopçu, 1989).
} 
fencing, there is a depth of information that can be directly applied or merely interesting background information.

Collectors of Persian weapons, museum curators and antique specialists will find much valuable information in this book. It and Khorasani's other two books (Khorasani, 2006, 2010) would make an excellent reference library for Persian weapons and armor. Historical re-enactors and even military model makers may find much to help them in the book. The illustrations give many examples of weapons and armor. People doing research on historical weapons will also find much to benefit their research in the text and illustrations. Lack of material on how people viewed and used their weapons has often been an impediment to a proper study of surviving artifacts.

What you get out of the book depends on what you are looking for. As an archer and a researcher, I found many new ideas and some resolutions of old problems. As a general reader of the other sections, I found much that was new and some positively intriguing bits of information. The book repays concentration with more information than a casual read through. There is a lot of ground covered and this book is more of a marathon than a stroll in the park. It is like an encyclopedia in many ways. It has many discrete pieces of information that can be absorbed by themselves, but it is not broken up into the artificial alphabetic structure that identifies an encyclopedia. A person reading this book can approach it as something to dip into at random for interesting facts or concentrate on a section to absorb the maximum amount of information on that subject. Not every reader will find the form and layout of this book congenial. It is not a set of manuals on the various subjects, but it is an excellent reference to them.

To people whose primary goal is to resurrect Persian martial arts, the book is a treasure trove of information. It would serve as a valuable reference for any training they might undergo. It can also serve as a starting point to discover lost techniques. No book can teach you a martial art; every skill requires some instruction. The translations in the archery section emphasize the importance of finding a good teacher. This can be difficult in the modern world so people do the best they can and this book can be a guide.

\section{5.- Problems with the book}

From the foregoing it is clear that there are many technical problems with creating a book of this type. For various reasons relating to the nature of the materials and the early state of studying them, compromises have to be made in the layout and the content. In many cases the exact translations of the vocabulary of the manuscripts is ambiguous and the author has conscientiously provided alternatives. While this is the most honest approach, it is not the easiest to read. For the reader, it interrupts the flow of the text and makes it more difficult to stay on topic as you read.

Compromises had to be made about the mix of illustrations and text. Much less information would have been conveyed by an artistically more pleasing mix of fewer, larger illustrations with the current text. If the book had been intended as a coffee table art publication, then that choice would have been appropriate, but it seems clear that the author was concentrating on providing information for people interested in the subjects at the expense of visual simplicity.

The functional necessity of locating the notes at the end of the book is opposed by the physical size of the book making it a chore to flip back and forth comparing the text to the notes. However, this same choice is made in many books with this much information. As in the case of the illustrations, simplification would have impoverished the book.

Probably the least important, but the most obvious is the transliteration. Using the modern Persian transliteration system makes it hard for non-Farsi speakers to recognize some names that have entered English literature through other languages. Omar Khayyam is one obvious case though to be honest the alternative is given in parentheses. Many names of Arabic origin are known with different spellings and these are hard to decipher. Even the well known names of Persian kings might evade recognition since they have often entered English through several intermediate languages. As person interested in linguistics, I find this fascinating, but I am aware that many people find it confusing. On the positive side, Khorasani has carefully followed the identical transcription in all his publications. In the same vein, the citation of sources while being 
academically correct might be adjusted for a more general audience. I think the non-academic reader would be more comfortable with a citation of the original title of a work rather than the most recent publication. Many of the books have existed in manuscript for hundreds of years and properly edited versions have only appeared recently. It is important to be able to find these but it would have been perhaps better to have relegated this task to the bibliography rather than the citation within the text. As with all the perceived problems, choice had to be made and perhaps the problem is more with the reader than the book.

\section{6.- Conclusion}

The author's sentiment about the book and Persian martial arts is clearly set forth in the beginning. "This book is not a teach-yourself manual" he states. He further notes in the disclaimer that the book can be used for "personal development in the field of martial arts and training, historical reenactment and historical weapons analysis and research" under suitable instruction. In this he echoes the ideas of some of the texts used as a basis of this work. In his previous books he has given a general history of weapons and armor in Iran and a detailed glossary of the Persian terminology. In the current book he has gone one step further and is showing how the weapons and associated techniques work.

The question is does the book succeed in its goal of elucidating the Persian system of martial arts. By giving a detailed picture, Khorasani has avoided the problem of giving a skewed view of the subject limited by the choice of paraphrase over original texts. This has resulted in a depth of information that may be a hazard to some readers. Perhaps for a more general reader, his book on arms and armor in Iran ${ }^{8}$ would be a better introduction to the subject. However, the martial artist, the archer and the fencer are well served by all the detail and the illustrations.

An academic could easily trawl through the book for usable quotes and valuable insights. A historical novelist would find much to flesh out the ideas of combat and individual training. An intelligent general reader could easily use the information in the book to assess the accuracy of the academic and the novelist. People interested in historical recreation will find a whole world to play in. People who practice martial arts from different traditions my find this book gives a valuable perspective on the other ways things can be done. If you have gone to the trouble of learning one martial art, you are probably curious about others even if you do not necessarily want to learn them.

Those people trying to rebuild and reinvigorate the traditional martial arts of Iran will get the most out of the book. People who enjoy Persian art, whether painting or metalwork, prose or poetry will have their understanding enriched by the context this book can give to the arts. There is a great deal of new information in this book often imperfectly known in the past from paraphrase and anecdote in Arabic and Turkish works saying "the Persians do this or did that". Now we can see what the Persians said themselves.

This book is clearly part of a larger project and a logical development from the earlier books and the many articles Khorasani has either written or co-authored. Each section could spawn a book of its own and future research will provide even more insight into traditional Persian martial arts. I think it is important to see Persian Archery and Swordsmanship in that context. Its many other uses are apparent as are its many potential audiences, but it forms the core of future studies and a foundation on which they can be based.

This is a major work of scholarship in a new field and has negotiated the complex problems of such an enterprise well. It will serve its many audiences and enrich the understanding of this part of Persian culture. Its lack of bellicosity is very refreshing in the field of martial arts and its thorough approach to its subjects is rewarding for the interested reader.

8 See above. 


\section{References}

Al-Sarraf, S. (2004). Mamluk Furūsīyyah Literature and Its Antecedents. Mamluk Studies Review, VIII, 141-200.

Dwyer, B., \& Khorasani, M. M. (2013). An Analysis of a Persian Archery manuscript written by Kapur Čand. Revista de Artes Marciales Asiáticas, 8(1), 1-12.

Faris, N. A., \& Elmer, R. R. (1945). Arab Archery An Arabic Manuscript of about A.D. 1500 "A Book on the Excellence of the Bow and Arrow. Princeton: Princeton Univertity Press.

Khorasani, M. M. (2006). Arms and Armor from Iran The Bronze Age to the End of the Qajar Period. Tübingen: Legat Verlag.

Khorasani, M. M. (2010). Lexicon of Arms and Armor from Iran: A Study of Symbols and Terminology. Tübingen: Legat.

Khorasani, M. M. (2013). Persian Archery and Swordsmanship: Historical Martial Arts of Iran. Frankfurt am Main: Niloufer Books.

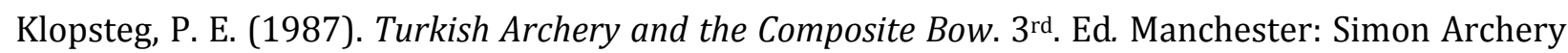
Foundation.

Latham, J., \& Paterson, W. (1970). Saracen Archery. London: Holland Press.

McEwen, E. (1974). Persian Archery Texts: Chapter Eleven of the Fakhr-i Muddabir's Ādāb al-Harb. Islamic Quarterly, XVII (3 \& 4).

Öztopçu, K. (2002). Kitāb fí 'Ílm an-Nuşşāb (Vol. 34). İstanbul: Türk Dilleri Araştırmaları Dizisi.

Öztopçu, K. (1989). Munyatu'l Ghuzat A 14th-Century Mamluk - Kipchak Military Treatise. Harvard: Harvard University.

Scanlon, G. (2012). A Muslim Manual of War. Retrieved from The American University in Cairo Press: http://www.aucpress.com/p-4740-a-muslim-manual-of-war.aspx.

\section{Appendix: List of Chapters}

1. Code Of Chivalry And Warrior Codex

2. The Sacred Weapon: Archery In Iran

3. Mounted Combat And Horse Classification In Persian Manuscripts

4. Combat With Spears And Lances In Iranian History

5. Swordsmanship

6. Maces And Axes In Iranian Martial Tradition

7. Combat With Short Edged Weapons In Iran

8. The Combat With Short Swords: Qame And Qaddāre

9. Wrestling: An Integral Part Of Combat In Iran

10. Persian Archery and Swordsmanship Catalog

11. References

12. Endnotes

\section{Author's biographical data}

Bede Dwyer (Australia) has pursued his interest in oriental archery for approximately 36 years of his adult life. In that time, he has researched the archery traditions of Turkey, Mamluk Egypt, Iran, Northern India, Mongolia, China and Korea. Rather than just compile information from old books, Bede has actively tested equipment and techniques and makes archers' rings, arrows, quivers and bow cases. Bede was the first person to shoot an arrow guide of the style of a Persian nāvak (Arabic majrā) in the American Flight Archery Tournament at Bonneville Flats in Utah. Bede also uses the Ottoman siper overdraw in flight shooting and 
briefly held a world distance record for shooting a hunting arrow with a traditional composite bow. For more than a decade Bede has been publishing articles in the Journal of the Society of Archer-Antiquaries on archaeological remains of archery equipment ranging from ancient repeating cross bows to medieval closed quivers. He is an active member of Razmafzar Organization dedicated to the study and academic research on historical Persian arms and armor and martial arts. E-mail: bededw@tpg.com.au 